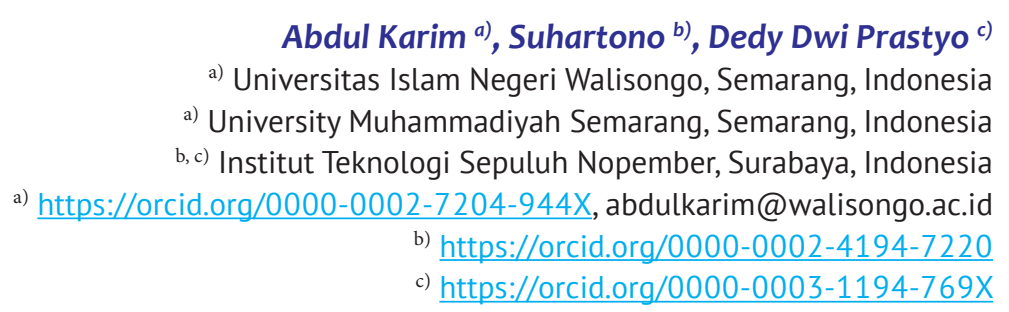

\title{
Spatial Spillover Effect Of Transportation Infrastructure On Regional Growth ${ }^{1}$
}

Increased connectivity between regions in Indonesia is believed to impact the productivity capacity of each region, as well as its economic growth. Moreover, the influence of connectivity on the surrounding area is commonly known as the indirect effect (spillover effect). This effect can increase the number of products, goods and services used as production factors. The study aims to examine the effect of transportation infrastructure on economic growth. We used spatial modelling to estimate the impact of transportation infrastructure on the economy of 34 provinces in Indonesia in 2017. We applied the spatial lag of X model (SLX), spatial autoregressive model (SAR), spatial error model (SEM), spatial autoregressive combined model (SAC), spatial Durbin model (SDM), spatial Durbin error model (SDEM), and spatial autoregressive combined mixed model (SAC mixed). According to the estimation results, the SAC mixed model is the best spatial model, as it has the smallest value of the Akaike information criterion (AIC) and significant coefficients of $\rho$ (rho) and $\lambda$ (lambda) parameters. The results show that the indicators "bus stations", "domestic investment" and "foreign investment" have a direct effect on the economic growth in 34 Indonesian provinces. In addition, we revealed the presence of indirect effects (spillovers) between provinces in Indonesia for the same variables.

Keywords: spatial econometrics, spatial spillover, Moran's Index, spatial modelling, spatial autoregressive, spatial error model, spatial Durbin model, spatial Durbin error model, transportation infrastructure, regional productivity

\section{Acknowledgments}

The article has been prepared with the financial support of the Ministry of Research, Technology and Higher Education of Republic of Indonesia (Project Scheme of National Competitive Research: National Collaborative Research Grant).

For citation: Karim, A., Suhartono \& Prastyo, D. D. (2020). Spatial Spillover Effect on Transportation Infrastructure if Regional Growth. Ekonomika regiona [Economy of region], 16(3), 911-920, https://doi.org/10.17059/ekon.reg.2020-3-18

\footnotetext{
1 () Abdul Karim, Suhartono, Dedy Dwi Prastyo. Text. 2020.
} 
ОРИГИНАЛЬНАЯ СТАТЬЯ

УДК: 332

\author{
А. Карим $^{\text {a) }}$, Сухартоно ${ }^{\text {б), Д. Д. Прастийо }}{ }^{\text {) }}$ \\ а) Государственный исламский университет «Валисонго», Семаранг, Индонезия \\ a) Университет Мухаммадия Семаранг, Семаранг, Индонезия \\ 6, в) Технологический институт Сурабая, Сурабая, Индонезия \\ a) https://orcid.org/0000-0002-7204-944X, abdulkarim@walisongo.ac.id \\ 6) https://orcid.org/0000-0002-4194-7220 \\ в) https://orcid.org/0000-0003-1194-769X
}

\title{
Влияние пространственного спилловер-эффекта транспортной инфраструктуры на региональный рост
}

Считается, что усиление связи между регионами Индонезии влияет как на производительность труда в каждом регионе, так и на экономический рост страны. Влияние существующих связей на прилегающую территорию приносит косвенные эфбекты (спилловер-эффекты), например, увеличение количества продуктов, товаров и услуг, используемых в качестве факторов производства. Целью исследования является изучение спилловер-эббекта влияния транспортной инфраструктуры на экономический рост. Для оценки влияния транспортной инфраструктуры на экономику 34 провиниий Индонезии в 2017 г. использована методика пространственного моделирования. Применены модель пространственного лага X (SLX), пространственная авторегрессионная модель (SAR), модель пространственной ошибки (SEM), пространственная авторегрессионная комбинированную модель (SAC), пространственная модель Дарбина (SDM), пространственная модель ошибки Дарбина (SDEM) и смешанная пространственная авторегрессионная комбинированная модель (смешанная SAC). Результать оценки показали, что смешанная модель SAС является наиболее подходящей: эта пространственная модель имеет наименьшее значение информационного критерия Акаике (АIC) и значимые коэфбициенты параметров $\rho$ (ро) и $\lambda$ (лямбда). Результать показывают, что показатели «автобусные станции», «внутренние инвестиции» и «иностранные инвестиции» имеют прямое влияние на экономический рост в 34 индонезийских провинциях. Кроме того, мы выявили наличие косвенных спилловер-эфбектов для тех же самых переменных в провинииях Индонезии.

Ключевые слова: пространственная эконометрика, пространственный спилл-овер эффект, индекс Морана, пространственное моделирование, пространственная авторегрессия, модель пространственной ошибки, пространственная модель Дарбина, пространственная модель ошибки Дарбина, транспортная инфраструктура, региональная производительность

\section{Благодарность}

Статья подготовлена при финансовой поддержке Министерства исследований, технологий и высшего образования Республики Индонезия (Схема национальных конкурентных исследований: грант на национальные совместные исследования).

Для цитирования: Карим А., Сухартоно, Прастийо Д. Д. Влияние пространственного спилл-овер эффекта транспортной инфраструктуры на экономический рост // Экономика региона. 2020. Т. 16, вып. 3. С. 911-920. https://doi.org/10.17059/ ekon.reg.2020-3-18

\section{Introduction}

According to the World Economic Forum [1] that analysed the pillars of infrastructure competitiveness, further examination of their constituent elements particularly related to transportation placed Indonesia's infrastructure on the 80th place. This result indicates that Indonesia was left behind, as Singapore ranked 3rd, Malaysia ranked 19th, and Thailand ranked 72nd. Overall, transportation infrastructures of the country (depending on various types of Indonesian transportation) lag behind Malaysia and Singapore. This tendency can be seen from Indonesia's Gross Domestic Product (GDP) that has been showing a downward trend, going from $5.56 \%$ in 2013 to $5.07 \%$ in 2017 [2].

The impact of transportation infrastructures on regional economic growth is the topic often discussed in the economic development literature. The research was initiated by Aschauer [3] who used infrastructure variables to define economic growth in the United States. Recent studies involving spatial spillover effects were conducted by Li et al. [4] and Wang et al. [5] who combined spatial models to analyse the effects of spatial spillover on transport infrastructures in China. Furthermore, Arbués et al. [6] examined the direct and indirect effects in the study of transportation infrastructures. The researchers assumed that an increase in transportation infrastructure services in one area (location) has an impact on the economy of the surrounding area. They call this condition the spillover effect.

Increased connectivity between regions in Indonesia is believed to impact the productivity 
capacity of each region, as well as its economic growth due to the increase in the number of products, goods and services used as production factors [7]. However, the transportation infrastructure development creates additional services and reduces travel costs. Besides, the improvement of transportation infrastructure can lead to an increase in the number of productive users.

In each region in Indonesia, there are various types of economic growth, depending on the differences in geographic characteristics or regional structures, including the value of capital, the number of workers and transportation infrastructure. This does not mean that each of these regions is independent or unaffected by other. Even though these consequences occur in areas of transportation infrastructure location, they may also spread to neighbouring regions [8]. Increased inter-regional connectivity and/or geographical proximity and characteristic similarities are strongly suspected to have spillover effects [9].

Ho \& Hesher [10] discussed the first law of geography proposed by Tobler, which states that the conditions at one point or area are related to those at the other adjacent point or area. This law is the basis for regional science studies. Frequently, the observations in a location depend on those in other locations. To overcome this, a regression model was developed using a spatial econometric approach. Spatial effect often occurred between two regions. In spatial data, the observation in one location usually depends on the observation in another adjacent (neighbouring) location.

The study aims to examine the direct and indirect effects (known as spillovers) of transportation infrastructures and other economic factors on the economic growth in Indonesia. As a tool to test the above statement, we estimated the elasticity of the economic growth of transportation infrastructure by using spatial econometric estimates of production functions and its processes.

\section{Materials}

\subsection{Spatial Econometrics Model}

Spatial econometric model is a development of econometric models. This economic phenomenon is relevant when considered from the perspective of location and others. Based on the first law of Tobler, the conditions at one point or area are related to the conditions at another point or adjacent area [11].

Ciccarelli \& Fachin [12] mentioned Anselin's description of two spatial effects in econometrics, namely, the effects of spatial dependence and spatial heterogeneity. Spatial dependence indicates the presence of autocorrelation between the examined locations (cross sectional data set). Spatial heterogeneity refers to the diversity of functional forms and parameters at each location. The examined locations show the non-homogeneity in the data. Generally, the spatial model can be expressed in the form of equation (1).

$$
\begin{gathered}
\mathbf{y}=\rho \mathbf{W y}+\mathbf{X} \beta+\mathbf{u}, \\
\mathbf{u}=\lambda \mathbf{W u}+\varepsilon, \\
\varepsilon \sim N\left(0, \sigma^{2} \mathbf{I}\right),
\end{gathered}
$$

where $\mathrm{y}$ is the $N \times 1$ vector of the dependent variable; $\mathbf{X}$ is the $N \times p$ matrix of the independent variable; $\beta$ is the $p \times 1$ vector of the regression coefficient, $W$ is the $N \times N$ weight matrix which states the relationships between $N$, $\rho$ and $\lambda$ which are the spatial parameters of dependency; $\varepsilon$ is error with independent and identically distributed values.

\subsection{Independent Spatial Lag Model}

The independent spatial lag model is a weighted linear regression model that is indicative of local regression model parameters. The spatial regression with lags in the independent variable is called the spatial lag of $X$ model (SLX) [13]. The $S L X$ model can be expressed as follows.

$$
\mathbf{y}=\mathbf{X} \beta+\mathbf{W} \mathbf{X} \gamma+\varepsilon,
$$

where $\mathrm{y}$ is the $N \times 1$ vector of the dependent variable; $\mathbf{X}$ is the $N \times p$ matrix of the independent variable; $\beta$ is the $p \times 1$ vector of regression coefficient; W is the $N \times N$ weight matrix which states the relationship between $N, \gamma$ which are the spatial dependency parameters; $\varepsilon$ is the normal, independent and identically distributed vector.

\subsection{Spatial Autoregressive Model}

Qu \& Lee [14], relying on Ord, introduced a method known as spatial autoregressive model (SAR). This model is used when there is a relationship between the observations (locations) of the variable $\mathbf{Y}$. It is written in the equation:

$$
y_{i}=\alpha_{i}+\rho \sum_{j=1}^{n} W_{i j} y_{j}+X_{i} \beta_{i}+\varepsilon_{i},
$$

and denoted in the matrix:

$$
\begin{gathered}
\mathbf{y}=\rho \mathbf{W} \mathbf{y}+\mathbf{X} \beta+\varepsilon, \\
(\mathbf{I}-\rho \mathbf{W}) \mathbf{y}=\mathbf{X} \beta+\varepsilon, \\
\mathbf{y}=(\mathbf{I}-\rho \mathbf{W})^{-1} \mathbf{X} \beta+(\mathbf{I}-\rho \mathbf{W})^{-1} \varepsilon,
\end{gathered}
$$

where $\left(\varepsilon_{i} \sim \operatorname{IIDN}\left(0, \sigma^{2}\right)\right), i=1 \ldots, n$.

\subsection{Spatial Error Model}

LeSage \& Pace [13] described the Spatial Error Model (SEM) in the form of the following equation: 


$$
\begin{gathered}
\mathbf{y}=\mathbf{X} \beta+\mathbf{u}, \\
\mathbf{u}=\lambda \mathbf{W u}+\mathrm{e},
\end{gathered}
$$

where $\mathbf{y}$ is the $n \times 1$ vector of the endogenous variable; $\mathbf{X}$ is the $n \times p$ matrix of the exogenous variable; $\beta$ is the $p \times 1$ vector of regression coefficient; $\mathbf{W}$ is the $n \times n$ spatial weight matrix, $\lambda$ is the spatial dependency parameter; $\varepsilon$ is the normal, independent and identically distributed vector. Equations (5) and (6) can be completed until obtaining $\mathbf{u}$,

$$
\mathbf{u}=(\mathbf{I}-\lambda \mathbf{W})^{-1} \varepsilon .
$$

From equations (5) and (7), it is obtained that:

$$
\mathbf{y}=\mathbf{X} \beta+(\mathbf{I}-\lambda \mathbf{W})^{-1} \varepsilon .
$$

\subsection{Spatial Autoregressive Combined (SAC)}

The Spatial Autoregressive Combined (SAC) model occurs when $\lambda \neq 0$ or $\rho \neq 0$. This spatial model contains spatial dependence in both variables, namely, the dependent and residual variables.

$$
\begin{gathered}
\mathbf{y}=\rho \mathbf{W} \mathbf{y}+\mathbf{X} \beta+\mathbf{u}, \\
\mathbf{u}=\lambda \mathbf{W u}+\varepsilon, \\
\mathbf{u}=\varepsilon \sim \mathbf{N}\left(0, \sigma^{2} I n\right)
\end{gathered}
$$

where $y$ is the $n \times 1$ vector of the response variable; $x$ is the $n \times \mathrm{p}$ matrix of the response variable; $\beta$ is the $p \times 1$ vector of regression coefficient; $\mathbf{W}$ is the $n \times n$ spatial weight matrix; $\lambda$ is the spatial response parameter; $\varepsilon$ is the vector with normal, identical, and independent distribution.

\subsection{Spatial Durbin Model}

The development of the SAR model mentioned in the previous section is mixed regressive-autoregressive spatial model, which is also called the Spatial Durbin Model (SDM) with the added spatial lag to the independent variables [15]. This model has the following equation form,

$$
\begin{gathered}
y_{i}=\rho \sum_{j=1}^{n} w_{i j} y_{j}+\beta_{0}+ \\
+\left(\beta_{11} x_{1 i}+\beta_{12} x_{2 i}+\ldots .+\beta_{1 k} x_{k i}+\ldots .+\beta_{11} x_{l i}\right)+ \\
+\left(\begin{array}{l}
\beta_{21} \sum_{j=1}^{n} w_{i j} x_{1 j}+\beta_{22} \sum_{j=1}^{n} w_{i j} x_{2 j}+\ldots+ \\
+\beta_{2 k} \sum_{j=1}^{n} w_{i j} x_{k j}+\ldots .+\beta_{2 l} \sum_{j=1}^{n} w_{i j} x_{l j}
\end{array}\right)+\varepsilon_{i} y_{i}= \\
=\rho \sum_{j=1}^{n} w_{i j} y_{j}+\beta_{0}+\sum_{k=1}^{l} \beta_{1 k} x_{k i}+\sum_{k=1}^{l} \beta_{2 k} \sum_{j=1}^{n} w_{i j} x_{k j}+\varepsilon_{i}
\end{gathered}
$$

when it is written in the form of matrix

$$
\mathbf{y}=\rho \mathbf{W} \mathbf{y}+\mathbf{Z} \beta+\varepsilon .
$$

With $\mathbf{Z}=\left[\begin{array}{lll}\mathbf{I} & \mathbf{X} & \mathbf{W X}\end{array}\right], \beta=\left[\begin{array}{lll}\beta_{0} & \beta_{1} & \beta_{2}\end{array}\right]^{T}$

\subsection{Spatial Durbin Error Model}

LeSage \& Pace [13] described the spatial model of SEM using the following equation:

$$
\begin{gathered}
\mathbf{y}=\mathbf{X} \beta+\mathbf{u}, \\
\mathbf{u}=\lambda \mathbf{W u}+\varepsilon .
\end{gathered}
$$

Equations (11) and (12) can be completed so that $\mathbf{u}$ is obtained:

$$
\mathbf{u}=(\mathbf{I}-\lambda \mathbf{W})^{-1} \varepsilon .
$$

From equations (12) and (13), it is obtained:

$$
\mathbf{y}=\mathbf{X} \beta+(\mathbf{I}-\lambda \mathbf{W})^{-1} \varepsilon .
$$

Then, [13] introduced the spatial Durbin error model (SDEM), adding the spatial lag in the independent variable

$$
y_{i}=\beta_{0}+\sum_{k=1}^{l} \beta_{1 k} x_{k i}+\sum_{k=1}^{l} \beta_{2 k} \sum_{j=1}^{n} w_{i j} x_{k j}+(I-\lambda W)^{-1} \varepsilon .
$$

It can be written in the form of matrix

$$
\mathbf{y}=\mathbf{Z} \beta+(\mathbf{I}-\lambda \mathbf{W})^{-1} \varepsilon,
$$

where $\mathbf{Z}=[\mathbf{I} \mathbf{X} \mathbf{W X}]$ and $\beta=\left[\begin{array}{lllll}\beta_{0} & \beta_{1} & \beta_{2} & \beta_{3} & \beta_{4}\end{array}\right]^{T}$, WX are the spatial lags in $\mathbf{X}$, and $\mathbf{I}$ is the identity matrix of $1 \times 1$.

\subsection{SAC Mixed Model}

In general, the SAC model does not have the element of WX, thus, it is not the same as HR. However, SAC can be developed through HR development as follows:

$$
\begin{gathered}
\mathbf{y}=\rho \mathbf{W y}+\mathbf{X} \beta+\mathbf{W} \mathbf{X} \gamma+\mathbf{u}, \\
\mathbf{u}=\lambda \mathbf{W u}+\varepsilon, \\
\mathbf{u}=\varepsilon \sim \mathbf{N}\left(0, \sigma^{2} I n\right),
\end{gathered}
$$

where $\mathbf{y}$ is the $n \times 1$ vector of the response variable; $\mathbf{x}$ is the $n \times p$ matrix on the response variable; $\beta$ is the $p \times 1$ vector of regression coefficient; $\mathbf{W}$ is the $n \times n$ spatial weight matrix; $\lambda$ is the spatial response parameter; $\varepsilon=$ vector with normal; identical; and independent distribution.

\section{Descriptions of Data, Variables and Model}

In this section, we discuss the data used in the model estimation. Indonesia is a country that applies the principle of decentralisation; it consists of 34 provinces. Each province has its own authority to regulate its economic activities. Indonesia is an archipelagic country where each province has different geographical, demographic and economic characteristics and conditions. This research was a development of the research conducted by Karim et al. [16] who used the spatial Durbin error model to examine the economic growth in Central Java province, focussing on regional regencies and cities. Our research differs from the study of [16], 
Definition of the variables

\begin{tabular}{|c|c|c|c|c|}
\hline No & Variable & Indicator & Analysis Unit & Data Source \\
\hline \multicolumn{5}{|c|}{ Dependent Variable } \\
\hline 1 & $\begin{array}{l}\text { Gross Domestic } \\
\text { Product (GDP) }\end{array}$ & Gross Domestic Product for each province & Rupiah & BPS-Statistics Indonesia \\
\hline \multicolumn{5}{|c|}{ Independent Variable } \\
\hline 2 & $\begin{array}{l}\text { Domestic Direct } \\
\text { Investment (DDI) }\end{array}$ & $\begin{array}{l}\text { Values of domestic investment for each } \\
\text { province }\end{array}$ & Rupiah & BPS-Statistics Indonesia \\
\hline 3 & $\begin{array}{l}\text { Foreign Direct } \\
\text { Investments (FDI) }\end{array}$ & $\begin{array}{l}\text { Values of foreign investment for each } \\
\text { province }\end{array}$ & Rupiah & BPS-Statistics Indonesia \\
\hline 4 & Labour & Values of labour for each province & Person & BPS-Statistics Indonesia \\
\hline 5 & Road & $\begin{array}{l}\text { Length of road in good and medium } \\
\text { condition }(\mathrm{Km}) \text { for each province }\end{array}$ & $\mathrm{Km}$ & BPS-Statistics Indonesia \\
\hline 6 & Bus Station (Bus) & Number of bus stations in each province & Unit & $\begin{array}{l}\text { Ministry of } \\
\text { Transportation }\end{array}$ \\
\hline 7 & Port & Number of ports in each province & Unit & $\begin{array}{l}\text { Ministry of } \\
\text { Transportation }\end{array}$ \\
\hline 8 & Airport (Air) & Number of airports in each province & Unit & $\begin{array}{l}\text { Ministry of } \\
\text { Transportation }\end{array}$ \\
\hline 9 & Export (Exp) & Value of Exports by Major Ports & Rupiah & BPS-Statistics Indonesia \\
\hline
\end{tabular}

as we use seven spatial modelling processes and examine the scope of the Indonesian provinces. Moreover, we added the variables of transportation infrastructure (ports, airports and bus stations), investment (domestic investment and foreign investment), and export. Table 1 shows the definitions of the variables used.

According to [13], there are several spatial econometric models that can be used, such as the spatial autoregressive model (SAR), spatial error model (SEM), and spatial autoregressive combined model (SAC). The special cases of the SAR and SEM models are the spatial Durbin model (SDM) and the spatial Durbin error model (SDEM) characterised by the presence of the indirect effect with the addition of dependent and independent lag effects. While the spatial Durbin error model (SDEM) does not enable the lag effect of the dependent variable, it enables the spatial lag error and the spatial lag in the independent variable. Besides, the combination of the SDM and SDEM models is known as the SAC mixed model with the presence of indirect effect as well as the added lag effect in the endogenous variable and lag error.

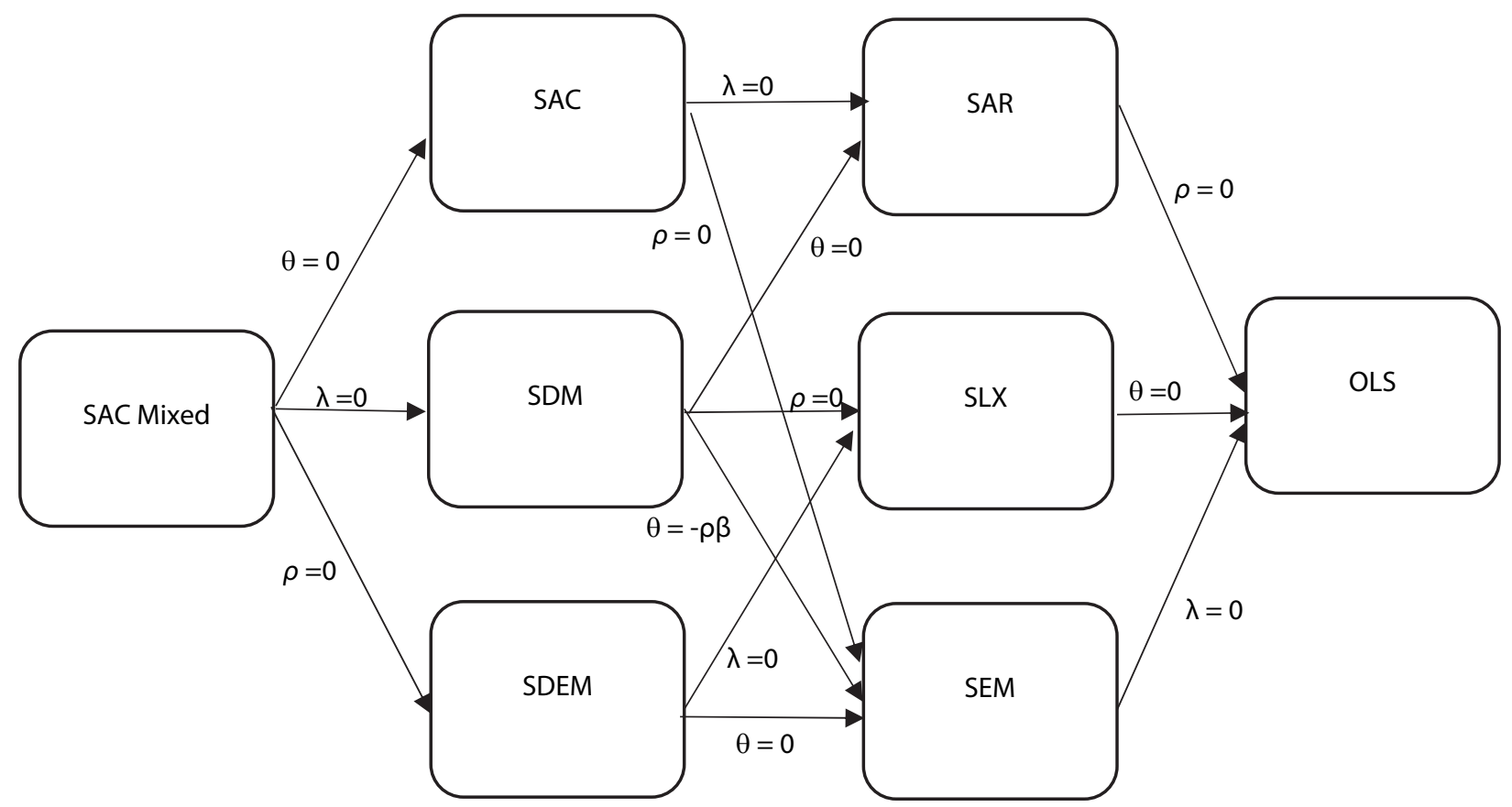

Figure 1. Comparison of specifications of different spatial econometric models 
Empirical model of spatial econometrics

\begin{tabular}{|c|}
\hline \multirow{2}{*}{$\frac{\text { Spatial Econometric Model }}{\text { Spatial Lag X }(S L X)}$} \\
\hline \\
\hline $\begin{array}{c}y_{i}=\beta_{0}+\beta_{1} X_{1}+\beta_{2} X_{2}+\beta_{3} X_{3}+\beta_{4} X_{4}+\beta_{5} X_{5}+\beta_{6} X_{6}+\beta_{7} X_{7}+\beta_{8} X_{8}+\beta_{9} X_{9}+ \\
+\theta_{1} W X_{1}+\theta_{2} W X_{2}+\theta_{3} W X_{3}+\theta_{4} W X_{4}+\theta_{5} W X_{5}+\theta_{6} W X_{6}+\theta_{7} W X_{7}+\theta_{8} W X_{8}+\varepsilon_{i}\end{array}$ \\
\hline Spatial Autoregressive Model (SAR) \\
\hline$y_{i}=\rho W y+\beta_{0}+\beta_{1} X_{1}+\beta_{2} X_{2}+\beta_{3} X_{3}+\beta_{4} X_{4}+\beta_{5} X_{5}+\beta_{6} X_{6}+\beta_{7} X_{7}+\beta_{8} X_{8}+\varepsilon_{i}$ \\
\hline Spatial Error Model (SEM) \\
\hline $\begin{array}{c}y_{i}=\rho W y+\beta_{0}+\beta_{1} X_{1}+\beta_{2} X_{2}+\beta_{3} X_{3}+\beta_{4} X_{4}+\beta_{5} X_{5}+\beta_{6} X_{6}+\beta_{7} X_{7}+\beta_{8} X_{8}+u_{i} \\
u_{i}=\lambda W u_{i}+\varepsilon_{i}\end{array}$ \\
\hline Spatial Autoregressive Combined Model (SAC) \\
\hline \multirow{2}{*}{$\begin{array}{c}y_{i}=\beta_{0}+\beta_{1} X_{1}+\beta_{2} X_{2}+\beta_{3} X_{3}+\beta_{4} X_{4}+\beta_{5} X_{5}+\beta_{6} X_{6}+\beta_{7} X_{7}+\beta_{8} X_{8}+u_{i} \\
u_{i}=\lambda W u_{i}+\varepsilon_{i} \\
\text { Spatial Durbin Model (SDM) }\end{array}$} \\
\hline \\
\hline $\begin{array}{c}y_{i}=\rho W y+\beta_{0}+\beta_{1} X_{1}+\beta_{2} X_{2}+\beta_{3} X_{3}+\beta_{4} X_{4}+\beta_{5} X_{5}+\beta_{6} X_{6}+\beta_{7} X_{7}+\beta_{8} X_{8}+ \\
+\theta_{1} W X_{1}+\theta_{2} W X_{2}+\theta_{3} W X_{3}+\theta_{4} W X_{4}+\theta_{5} W X_{5}+\theta_{6} W X_{6}+\theta_{7} W X_{7}+\theta_{8} W X_{8}+\varepsilon_{i}\end{array}$ \\
\hline Spatial Durbin Error Model (SDEM) \\
\hline $\begin{array}{c}y_{i}=\beta_{0}+\beta_{1} X_{1}+\beta_{2} X_{2}+\beta_{3} X_{3}+\beta_{4} X_{4}+\beta_{5} X_{5}+\beta_{6} X_{6}+\beta_{7} X_{7}+\beta_{8} X_{8}+ \\
+\theta_{1} W X_{1}+\theta_{2} W X_{2}+\theta_{3} W X_{3}+\theta_{4} W X_{4}+\theta_{5} W X_{5}+\theta_{6} W X_{6}+\theta_{7} W X_{7}+\theta_{8} W X_{8}+u_{i} \\
u_{i}=\lambda W u_{i}+\varepsilon_{i}\end{array}$ \\
\hline Spatial Autoregressive Combined Mixed Model (SAC Mixed) \\
\hline $\begin{array}{c}y_{i}=\rho W y+\beta_{0}+\beta_{1} X_{1}+\beta_{2} X_{2}+\beta_{3} X_{3}+\beta_{4} X_{4}+\beta_{5} X_{5}+\beta_{6} X_{6}+\beta_{7} X_{7}+\beta_{8} X_{8}+ \\
+\theta_{1} W X_{1}+\theta_{2} W X_{2}+\theta_{3} W X_{3}+\theta_{4} W X_{4}+\theta_{5} W X_{5}+\theta_{6} W X_{6}+\theta_{7} W X_{7}+\theta_{8} W X_{8}+u_{i}, \\
u_{i}=\lambda W u_{i}+\varepsilon_{i}\end{array}$ \\
\hline
\end{tabular}

The estimated empirical model was based on the log-linear Cobb-Douglas function. The following Table presents the spatial econometric models, as we estimated seven spatial modelling processes.

\section{Results and Discussion}

\subsection{Spatial Dependence}

We used global Moran's Index (Moran's I) to test the presence of the phenomenon of economic agglomeration, as Moran's I indicates the spatial dependence coefficient of inter-province based on the variables used, which range between -1 and 1 [17]. In this paper, we tested spatial dependencies to analyse 34 provinces, which affected economic growth and its factors.

The values of global Moran's I in Table 3 show that the index positive and significant for economic growth, domestic investment, labour, and airports. Therefore, we conclude that economic growth in Indonesia has a strong spatial dependence.

Furthermore, we conducted diagnostic tests of Lagrange Multiplier $(L M)$ on the residuals of ordinary least squares $(O L S)$ to determine whether there are any spatial dependencies. This step is
Table 3

Global Moran's I

\begin{tabular}{|c|c|c|}
\hline Variables & Moran's I Statistics & $\boldsymbol{p}$-value \\
\hline GDP & 0.504 & $0.000^{* * *}$ \\
\hline DDI & 0.366 & $0.022^{* *}$ \\
\hline FDI & 0.049 & 0.297 \\
\hline Labour & 0.429 & $0.000^{* * *}$ \\
\hline Road & 0.05 & 0.295 \\
\hline Bus & 0.178 & $0.074^{*}$ \\
\hline Port & 0.02 & 0.36 \\
\hline Air & 0.357 & $0.004^{* *}$ \\
\hline Exp & -0.213 & 0.889 \\
\hline
\end{tabular}

* Significance code: $p<0.1$.

${ }^{* *}$ Significance code: $p<0.05$.

${ }^{* * *}$ Significance code: $p<0.01$.

important, as it is necessary to determine which spatial model is right $[18,19]$ (Table 4).

Because Moran's I (error) is significant and has positive spatial dependencies, it is necessary to consider the geographical attributes in the modelling. Furthermore, five tests of Lagrange Multiplier diagnostics indicate that the best model is a model involving the parameters of rho $(\rho)$ and lambda $(\lambda)$. 


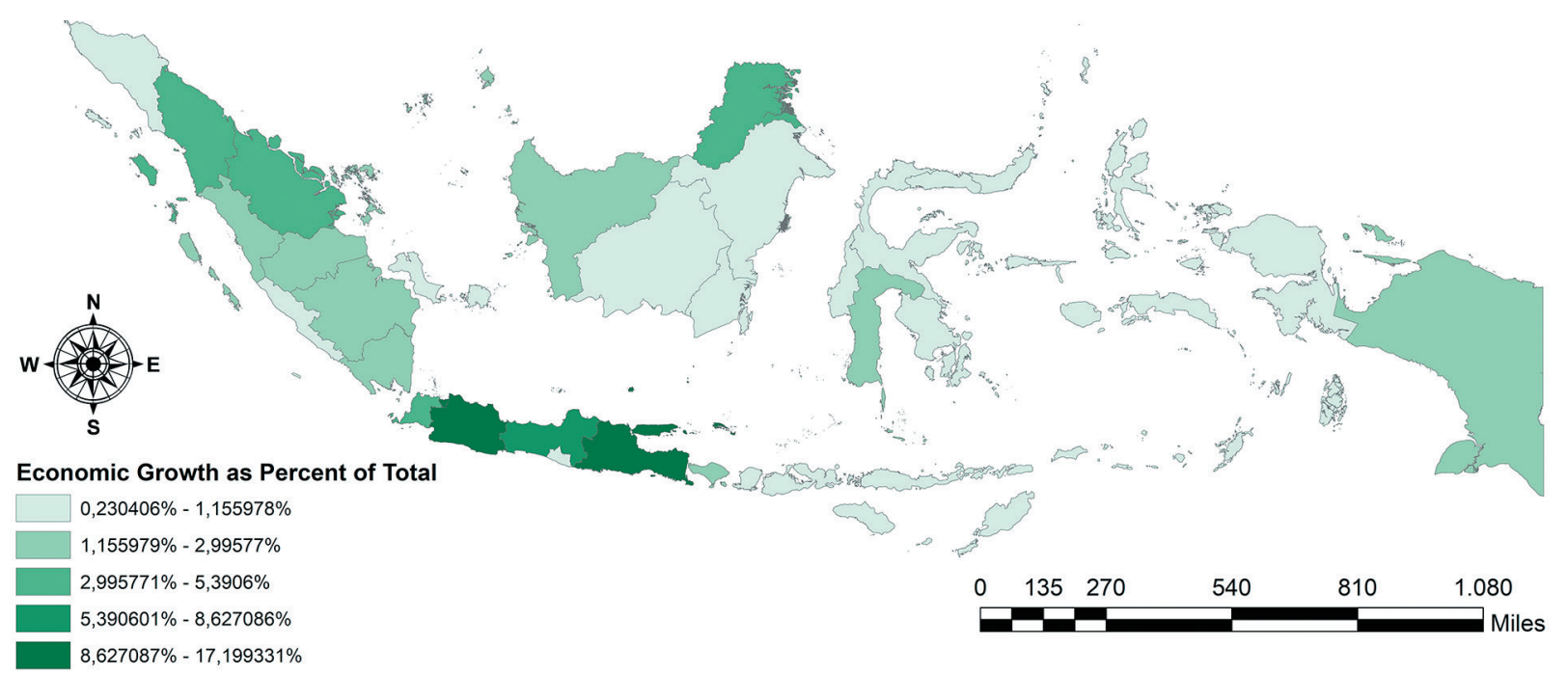

Figure 2. Rates of economic growth in terms of GDP of the provinces in Indonesia in 2017

Table 4

Lagrange Multiplier diagnostic test for spatial dependence

\begin{tabular}{|l|c|c|}
\hline $\begin{array}{c}\text { Lagrange multiplier } \\
\text { diagnostics }\end{array}$ & Statistics & p-value \\
\hline Moran's I (error) & 0.355 & $0.004^{* * *}$ \\
\hline$L M$ (error) & 5.171 & $0.022^{* *}$ \\
\hline$L M$ (lag) & 3.895 & $0.048^{* *}$ \\
\hline Robust $L M$ (error) & 5.270 & $0.021^{* *}$ \\
\hline Robust $L M$ (lag) & 3.994 & $0.045^{* *}$ \\
\hline SARMA & 9.165 & $0.010^{* *}$ \\
\hline
\end{tabular}

* Significance code: $p<0.1$.

** Significance code: $p<0.05$.

** Significance code: $p<0.01$.

\subsection{Spatial Econometric Models}

Figure 2 shows that high economic growth rates are found in most parts of Java. Rates of economic growth are lower in several provinces in Sumatra and Sulawesi. Other regions, such as parts of Sulawesi and Sumatra, Kalimantan, Nusa Tenggara Timur, Nusa Tenggara Barat, Bali, Maluku and Papua tend to have low economic growth rates. These data indicate that economic growth in Indonesia has not been evenly distributed. This distribution is still dominated by Java Island, while other regions are lagging behind in terms of economic growth. In addition, Figure 2 shows the distribution of economic growth for each province. This fact confirms that the use of the Queen spatial weight matrix $(\mathbf{W})$ is advisable for economic growth modelling in Indonesia.

Based on the spatial econometric models in Table 5, we examined the linkages between transportation infrastructure (and other factors) and regional economic growth in Indonesia. The results show that the SAC mixed model has the smallest value of the Akaike information crite- rion (AIC), meaning that the SAC mixed is more suitable than other spatial econometric models. Because we had determined that the SAC mixed model involved spatial lags for the dependent variables, independent variables and residual components, in this section we focused on discussing the results of the SAC mixed model. Overall, the results were obtained by estimating the SAC mixed model using a queen spatial weight matrix and calculating the direct and indirect effects. We have made several conclusions. First, the parameters $\rho$ and $\lambda$ (which represent spatial effects of economic growth) are significant and positive. This fact indicates the presence of a geographical link in economic growth in Indonesia. These results are consistent with the findings from previous studies conducted with the help of spatial autocorrelation analysis showing spatial dependence in economic growth. Note that the positive and significant effect of the spatial lag of the dependent variable and the spatial lag of the residual, which show the values of 0.118 and 0.263 , depend on the specification of $\mathbf{W}$ used. These results indicate that the average weight of economic growth in neighbouring provinces positively and significantly affects changes in economic growth in certain provinces. Here, when the values of the spatial lag of the dependent variable and the spatial lag of the residual are positive, the economic sectors in one province will increase the growth capacity of the economic sectors in other provinces.

\subsection{Spatial econometric models}

Second, according to the results of the SAC mixed model, the direct effects of labour and road infrastructure on economic growth of certain provinces are positive and very significant. In addition, the values of labour elasticity around 0.242 
Table 5

Spatial econometric models

\begin{tabular}{|c|c|c|c|c|c|c|c|c|}
\hline & OLS & $S L X$ & SAR & SEM & $S A C$ & SDM & SDEM & $S A C$ mixed \\
\hline \multicolumn{9}{|c|}{ Direct effects } \\
\hline Intercept & $19.879^{* * *}$ & $20.666^{* * *}$ & $19.925^{* * *}$ & $19.893^{* * *}$ & $19.857^{* * *}$ & $20.599^{* * *}$ & $21.349^{* * *+}$ & $21.307^{* * *}$ \\
\hline DDI & 0.009 & 0.000 & 0.004 & 0.017 & 0.014 & -0.001 & $-0.044^{*}$ & $-0.041^{*}$ \\
\hline FDI & 0.041 & 0.036 & 0.049 & $0.053^{* *}$ & $0.056^{* *}$ & $0.048^{*}$ & 0.020 & 0.024 \\
\hline Labour & 0.058 & 0.172 & $0.116^{*}$ & 0.001 & 0.035 & $0.109^{*}$ & $0.263^{* * *}$ & $0.242^{* * *}$ \\
\hline Road & 0.127 & 0.270 & $0.203^{* *}$ & $0.181^{*}$ & $0.196^{* *}$ & $0.268^{* * *}$ & $0.317^{* * *}$ & $0.315^{* * *}$ \\
\hline Bus & -0.040 & 0.006 & -0.009 & -0.051 & -0.031 & -0.017 & -0.027 & -0.034 \\
\hline Port & -0.030 & -0.023 & -0.028 & -0.035 & -0.034 & -0.025 & -0.015 & -0.015 \\
\hline Air & $-0.084^{*}$ & -0.092 & $-0.110^{* * *}$ & $-0.080^{*}$ & $-0.089^{* *}$ & $-0.088^{*}$ & $-0.112^{* * *}$ & $-0.109^{* * *}$ \\
\hline Exp & -0.005 & -0.011 & $-0.006^{*}$ & -0.002 & -0.003 & $-0.008^{*}$ & $-0.013^{* \star *}$ & $-0.013^{* * *}$ \\
\hline \multicolumn{9}{|c|}{ Indirect effects } \\
\hline $\mathrm{W} \times \mathrm{DDI}$ & & -0.023 & & & & $-0.027^{*}$ & $-0.074^{* * *}$ & $-0.076^{* * *}$ \\
\hline $\mathrm{W} \times \mathrm{FDI}$ & & -0.019 & & & & -0.022 & $-0.040^{*}$ & $-0.046^{* *}$ \\
\hline $\mathrm{W} \times$ Labour & & 0.123 & & & & $0.132^{* *}$ & $0.317^{* * *}$ & $0.323^{* * *}$ \\
\hline $\mathrm{W} \times$ Road & & -0.125 & & & & -0.111 & -0.048 & -0.076 \\
\hline $\mathrm{W} \times$ Bus & & 0.041 & & & & 0.046 & $0.068^{* *}$ & $0.076^{* * *}$ \\
\hline $\mathrm{W} \times$ Port & & 0.005 & & & & -0.008 & -0.022 & $-0.024^{*}$ \\
\hline $\mathrm{W} \times$ Air & & 0.009 & & & & 0.018 & -0.013 & 0.002 \\
\hline $\mathrm{W} \times \operatorname{Exp}$ & & -0.005 & & & & -0.003 & $-0.008^{* * *}$ & $-0.007^{* * *}$ \\
\hline$\rho$ (Rho) & & & $-0.001^{* *}$ & & -0.001 & $0.208^{* * *}$ & & $0.118^{*}$ \\
\hline$\lambda$ (Lambda) & & & & $0.221^{* * *}$ & $0.199^{* * *}$ & & $0.265^{* * *}$ & $0.263^{* * *}$ \\
\hline AIC & -12.678 & -6.932 & -14.835 & -19.283 & -18.854 & -13.944 & -33.069 & -33.711 \\
\hline
\end{tabular}

* Significance code: $p<0.1$; ${ }^{* *}$ Significance code: $p<0.05$; ${ }^{* *}$ Significance code: $p<0.01$

and road infrastructure of 0.315 are positive and significant, indicating that they are very stable. Domestic investments, airports and export have a negative impact on the economies of provinces in Indonesia. While this finding can be considered unexpected, we discovered that some previous studies have obtained similar results. The estimated direct impacts of foreign investment, terminals and ports are also insignificant, regardless of empirical specifications.

Third, the indirect effect in the independent variables of the SAC mixed model influenced the presence and size of the spillover effect between the provinces. We found evidence of positive and significant spatial spillovers only for bus stations at 0.076 value. The direct effect of the "port" variable is negative but significant. Furthermore, airports and roads are not significant in indirect estimates. In addition, indirect estimation makes the variables of domestic investment, labour, and exports have the same mark and significance in the direct effect. Meanwhile, the foreign investment variable has a different sign from the direct effect, as the indirect effect has a negative and significant value.

According to the SAC mixed model, the improvement of the provincial bus station has positive and significant effect (alpha 1 per- cent) while the port infrastructure has negative and significant effect (alpha 10 percent). This result indicates that the development of bus transportation infrastructure positively and significantly impacts the economic growth of the surrounding area, while the port infrastructure needs to be developed massively, even though the confidence level is only 90 percent (alpha 10 percent). Conversely, the improvement of airport infrastructure and roads in a province will not cause spillover effects through migration of productive factors to neighbouring provinces. Furthermore, the increases in domestic investment, foreign investment, and exports in a province create negative spillover to the surrounding provinces. However, an increase in the number of employees in a province has a positive spillover effect on the closest province.

The above findings have sufficient evidence of the presence of spillovers for various types of transport infrastructures; they are consistent with the majority of academic studies using spatial data. For example, Alvarez et al. [20] found neither positive nor negative spillovers in the model they assessed. Delgado \& Álvarez [21] discovered the presence of positive and negative spillover effects in the model determined by the use of spatial weight matrix and the examined economic phe- 
nomena. Moreno \& López-Bazo [22] conclude the presence of negative spatial spillovers in the development of transportation infrastructure.

\section{Conclusion}

In this study, we tried to determine the appropriate model specifications to measure the effect of transportation infrastructure and other economic variables in the Indonesian economy. Based on the estimation results, the SAC mixed model is the best spatial model due to the smallest AIC value and significant coefficients of rho and lambda parameters. The results of the SAC mixed model show that the economic sectors in a province in Indonesia will increase the growth capacity of economic sectors in other adjacent provinces. In addition, several direct and indirect variables have significant effects confirming the presence of the spillover effect in economic growth in Indonesia.

Based on the findings above, there are several policy implications. First, economic growth in Indonesia has significant spatial dependencies, indicating that it is necessary to strengthen the provincial governments, considering a broader perspective and creating targeted regional economic policies. The implementation of regional economic policies should be based on collaborations with the surrounding regions. In particular, the territory of Indonesia that consists of islands should be considered a key area, and it is necessary to promote the equitable distribution of transportation infrastructure as a driver of regional economic growth.

Second, the provincial governments should focus on regional economic growth, and improve the realisation of domestic and foreign investment, employment and export expansion to various partner countries. Simultaneously, to increase economic growth, it is advisable to comprehensively strengthen various transportation infrastructures as they play an important role of inter-provincial connectivity tools in the movement of goods and services.

\section{References}

1. Schwab, K. (Ed.). (2017). The Global Competitiveness Report 2016-2017. Geneva, Switzerland: World Economic Forum. Retrieved from: https://www.weforum.org/reports/the-global-competitiveness-report-2016-2017-1 (Date of access: 01.09.2020).

2. Badan Pusat Statistik Indonesia. (2018). Statistik Indonesia 2018. Jakarta: Badan Pusat Statistik.

3. Aschauer, D. A. (1989). Is public expenditure productive? Journal of Monetary Economics, 23(2), 177-200. DOI: https://doi.org/10.1016/0304-3932(89)90047-0.

4. Li, J., Wen, J. \& Jiang, B. (2017). Spatial Spillover Effects of Transport Infrastructure in Chinese New Silk Road Economic Belt. International Journal of E-Navigation and Maritime Economy, 6, 1-8. DOI: 10.1016/J.ENAVI.2017.05.001.

5. Wang, Z., Xu, G., Bao, C., Xu, J. \& Sun, F. (2017). Spatial and economic effects of the Bohai Strait Cross-Sea Channel on the transportation accessibility in China. Applied Geography, 83, 86-99. DOI: 10.1016/J.APGEOG.2017.04.002.

6. Arbues, P., Banos, J. F. \& Mayor, M. (2015). The spatial productivity of transportation infrastructure. Transportation Research Part A: Policy and Practice, 75, 166-177. DOI: https://doi.org/10.1016/j.tra.2015.03.010.

7. Bengoa, M., Roman, V. M.-S. \& Perez, P. (2017). Do R\&D activities matter for productivity? A regional spatial approach assessing the role of human and social capital. Economic Modelling, 60, 448-461. DOI: https://doi.org/10.1016/J. ECONMOD.2016.09.005.

8. Xie, R., Fang, J. \& Liu, C. (2016). Impact and Spatial Spillover Effect of Transport Infrastructure on Urban Environment. Energy Procedia, 104, 227-232. DOI: 10.1016/J.EGYPRO.2016.12.039.

9. Zhang, L. (2017). The knowledge spillover effects of FDI on the productivity and efficiency of research activities in China. China Economic Review, 42, 1-14. DOI: 10.1016/J.CHIECO.2016.11.001.

10. Ho, C. Q. \& Hensher, D. A. (2016). A workplace choice model accounting for spatial competition and agglomeration effects. Journal of Transport Geography, 51, 193-203. DOI: 10.1016/j.jtrangeo.2016.01.005.

11. Joo, D., Woosnam, K. M., Shafer, C. S., Scott, D. \& An, S. (2017). Considering Tobler's first law of geography in a tourism context. Tourism Management, 62, 350-359. DOI: 10.1016/J.TOURMAN.2017.03.021.

12. Ciccarelli, C. \& Fachin, S. (2016). Regional growth with spatial dependence: A case study on early Italian industrialization. Papers in Regional Science, 21. DOI: 10.1111/pirs.12217.

13. LeSage, J. P. \& Pace, R. K. (2009). Introduction to spatial econometrics. CRC Press, 321.

14. Qu, X. \& Lee, L. (2015). Estimating a spatial autoregressive model with an endogenous spatial weight matrix. Journal of Econometrics, 184(2), 209-232. DOI: 10.1016/j.jeconom.2014.08.008.

15. Abate, G. D. \& Anselin, L. (2016). House price fluctuations and the business cycle dynamics. CREATES Research Papers 2016-06. Department of Economics and Business Economics, Aarhus University, 28.

16. Karim, A., Faturohman, A., Suhartono, S., Prastyo, D. D. \& Manfaat, B. (2017). Regression Models for Spatial Data: An Example from Gross Domestic Regional Bruto in Province Central Java. Jurnal Ekonomi Pembangunan: Kajian Masalah Ekonomi Dan Pembangunan, 18(2), 213-224. DOI: 10.23917/jep.v18i2.4660. 
17. Lottmann, F. (2012). Spatial dependencies in German matching functions. Regional Science and Urban Economics, 42(1), 27-41. DOI: 10.1016/j.regsciurbeco.2011.04.007.

18. Anselin, L., Bera, A. K., Florax, R. \& Yoon, M. J. (1996). Simple diagnostic tests for spatial dependence. Regional Science and Urban Economics, 26(1), 77-104. DOI: 10.1016/0166-0462(95)02111-6.

19. Baltagi, B. H., Feng, Q. \& Kao, C. (2012). A Lagrange Multiplier test for cross-sectional dependence in a fixed effects panel data model. Journal of Econometrics, 170(1), 164-177. DOI: 10.1016/j.jeconom.2012.04.004.

20. Alvarez, A., Arias, C. \& Orea, L. (2006). Econometric testing of spatial productivity spillovers from public capital. Hacienda Publica Espanola, 178(3), 9-21.

21. Delgado, M. J. \& Alvarez, I. (2007). Network infrastructure spillover in private productive sectors: evidence from Spanish high capacity roads. Applied Economics, 39(12), 1583-1597. DOI: 10.1080/00036840500486557.

22. Moreno, R. \& Lopez-Bazo, E. (2007). Returns to Local and Transport Infrastructure under Regional Spillovers. International Regional Science Review, 30(1), 47-71. DOI: 10.1177/0160017606296728.

\section{About the authors}

Abdul Karim - M. Sc., Junior Research Associate, Department of Statistics, University Muhammadiyah Semarang; Universitas Islam Negeri Walisongo; Scopus Author ID: 57196185152; https://orcid.org/0000-0002-7204-944X (Semarang, Jawa Tengah, 50273; Semarang, Central Jawa, 50185, Indonesia; e-mail: abdulkarim@unimus.ac.id, abdulkarim@walisongo. ac.id).

Suhartono - Dr. Sci. (Stat.), Senior Research Associate, Department of Statistics, Institut Teknologi Sepuluh Nopember; Scopus Author ID: 34980102200; https://orcid.org/0000-0002-4194-7220 (Sukolilo, Surabaya, East Jawa, 60111, Indonesia; e-mail: suhartono@statistika.its.ac.idmailto:ivanov@www.ru).

Dedy Dwi Prastyo - Dr. Rer. Pol., Senior Research Associate, Department of Statistics, Institut Teknologi Sepuluh Nopember; Scopus Author ID: 56866220100; https://orcid.org/0000-0003-1194-769X (Sukolilo, Surabaya, East Jawa, 60111, Indonesia; e-mail: dedy-dp@statistika.its.ac.idmailto:ivanov@www.ru).

\section{Информация об авторах}

Абдул Карим - магистр естественных наук, младший научный сотрудник, Департамент статистики, Университет Мухаммадия Семаранг; Государственный исламский университет «Валисонго»; Scopus Author ID: 57196185152; https://orcid.org/0000-0002-7204-944X (Индонезия, 50273, Центральная Ява, г. Семаранг; 50185, Центральная Ява, г. Семаранг; Indonesia e-mail: abdulkarim@unimus.ac.id, abdulkarim@walisongo.ac.id).

Сухартоно - доктор статистики, старший научный сотрудник, Департамент статистики, Технологический институт Сурабая; Scopus Author ID: 34980102200; https://orcid.org/0000-0002-4194-7220 (Индонезия, 60111, Восточная Ява, г. Сурабая, Суколило; e-mail: suhartono@statistika.its.ac.id).

Деди Дви Прастйо - доктор общественно-политических наук, старший научный сотрудник, Департамент статистики, Технологический институт Сурабая; ID автора Scopus: 56866220100; https://orcid.org/0000-0003-1194769X (Индонезия, 60111, Восточная Ява, г. Сурабая, Суколило; e-mail: dedy-dp@statistika.its.ac.id).

Дата поступления рукописи: 16.05.2019.

Прошла рецензирование: 19.11.2019.

Принято решение о публикации: 10.06.2020. 